\title{
VJERA I PASTORAL
}

Alojzije Čondić

Sveučilište u Splitu

Katolički bogoslovni fakultet alcondic@gmail.com
UDK: [27-282.3:2-766]:(4)(497.5) https://doi.org/10.34075/cs.55.4.2 Pregledni znanstveni rad Rad zaprimljen 1/2020.

\section{Sažetak}

U osnoune pastoralne izazove koje nameće sekularizacija ulazi vjerska ravnodušnost, odnosno smanjenje vjerskoga života $i$ nedostatka osjećaja crkvenosti. Ako se uzme da je vjera put kojim se može spasiti, onda se vjera i njezina primjena u životu odnosi na bît Crkve i njezina poslanja. Sukladno tomu pisac, teološko-pastoralnim načinom evanđeoske prosudbe, na temelju znanstvenih istraživanja, povezuje odnos vjere i pastorala u crkvenom životu, u Europi i Hrvatskoj, a potom govori o uzrocima i razlozima smanjenja vjere i crkvenosti. Raščlanjujući kulturno surječje hrvatskoga društva i pastoralni rad, govori o vjeri kao milosnom daru, za koji treba stvarati plemenito ozračje, da bi se što plodonosnije umnožila u vjernicima. Potom autor predlaže pastoralne smjernice o nužnosti pastoralne metanoje i načinu produbljenja vjere $i$ crkvenosti.

Ključne riječi: crkvenost, vjera, pastoral, kultura, razum, evangelizacija, navještaj.

\section{UvOD}

Govor o vjeri odnosi se na "radost i nadu, žalost i tjeskobu"1 svih ljudi, tiče se svih plemenitosti i nevoljâ, koje uznemiruju ljudski život. Prva i odlučujuća poteškoća odnosi se na vjerovanje, tj. na odnos čovjeka prema Bogu i oživotvorenost vjere, jer življenje vjere, kako naučava deklaracija Dignitatis humanae, sastoji se u unutarnjim dragovoljnim i slobodnim činima, kojima se čovjek izrav-

1 Drugi vatikanski koncil, Pastoralna konstitucija o Crkvi u suvremenom svijetu Gaudium et spes, Kršćanska sadašnjost (dalje: KS), Zagreb, ${ }^{7} 2008 .$, 1, (dalje: GS). 
no usmjeruje prema Bogu. ${ }^{2}$ U tomu se, zajedno s vjerom, nameće istina, jer suvremeno doba stvara kulturu bez vjerskih i normativnih načina. Na neki se način, razmišljanje o vjeri u doba sekularizacije i 'slabe misli' odnosi na ljudska prava i dostojanstvo ljudskoga razuma, jer intellectus querens fides. Crkva je pozvana trajno se osposobljivati, pomoću prvoga navještaja i nove evangelizacije, ponovno otvarati obzorje traženja istine, čiji se temelj odnosi na vjeru, jer "među raznim oblicima služenja koje ljudima treba ponuditi, ona uviđa da joj je jedno osobito vlastito: služenje istini”3.

Teološko-pastoralno posuvremenjenje odnosa istine i vjere bît je crkvenoga poslanja, jer u svijetu, koji je većinom razočaran i rastrojen, u kojemu se poticaji za dubinskim izazovima i pitanjima sve više uspavljuju, a tehnološki napredak i znanstveni pothvati neosporno utječu kao gospodari, svaki govor o određenim stvarnostima, apsolutnim i onostranim, crkvenim i vjerskim, usuđuje se neizbježno protumačiti kao bajoslovni i ideološki, zaostali i suvišni. U crkvenomu vidu, poteškoća važnosti prvoga navještaja vjere i nove evangelizacije često je prozvana, ali rijetko je, s teološko-pastoralnoga stajališta, ozbiljno i sustavno raspravljena i pretočena, a upravo je nerazložno umnažanje i nepovezanost pastorala izričiti znak toga. Radi se o razini crkvene osviještenosti kršćana, kako pastira, tako vjernika laika, jer kršćansku vjeru ne smiju zarobiti oblici pastoralne ravnodušnosti, inačice nasrtljivoga relativizma ili krute bezbrižnosti. ${ }^{4}$

Posljedice nespremnog suočivanja s društveno-kulturnim izazovima, ubrzanim promjenama i zahtjevima vremena za pastoralni zaokret nesagledivo se odražavaju na život u vjeri. Opasno je živjeti mentalno i pastoralno samo u prošlosti. Međutim, može li se vjera samo pretpostavljati, kao nešto posve sigurno u zajedničkomu životu, odnosno može li se samo, neusiljeno i tradicionalnim pastoralnim oblicima održavati i poticati njezin rast u novomu kulturnom okružju? Prije dvadesetak godina hrvatski su se biskupi s pravom upitali: „Kako evangelizirati našu domovinu Hrvatsku u kojoj su sve vidljivije i prisutnije posljedice sekularizacije i tragovi sekularizma?"5

2 Usp. Drugi vatikanski koncil, Deklaracija o slobodi vjerovanja Dignitatis humanae, KS, Zagreb, ${ }^{7} 2008 ., 3$.

3 Ivan Pavao II., Enciklika Fides et ratio, KS, Zagreb, 1999., br. 2., usp. br. 28. (dalje: FR).

4 Usp. Sergio Lanza, La parrocchia in un mondo che cambia, OCD, Roma Morena, 2003., 103-106.

5 Hrvatska biskupska konferencija, Pastoralne smjernice na početku trećeg tisućljeća Na svetost pozvani, Glas Koncila (dalje: GK), Zagreb, 2002., 10. 
Od tada do danas društvo se još više promijenilo, pa je to sada još teže, a pastoralno stanje ionako je teško, jer se radi o sve većemu prijeporu vjere. Velika je odgovornost na crkvenomu vodstvu da se ne prepusti pastoralnoj spontanosti, nego da, provjeravajući znakove vremena, potiče prikladan pastoral i učinkovit način evangelizacije. Papa Benedikt XVI. (2005.-2013.) je proglašujući Godinu vjere, mudro rekao: "Dok je u prošlosti bilo moguće prepoznati jedinstvenu kulturnu matricu, koja je naširoko prihvaćena u svojem podsjećanju na sadržaje vjere i na vrijednosti koje ona nadahnjuje, danas se čini kako, zbog duboke krize vjere kojom su pogođene mnoge osobe, to nije slučaj u velikim područjima društva."6.

Da je stanje veoma ozbiljno, odnosno da je kriza vjere najveći izazov za Crkvu suvremenoga doba, može se prepoznati iz govora pape Franje suradnicima u Rimskoj kuriji. Papa je zabrinuto upozorio: "Mi više nismo u kršćanstvu! Danas više nismo jedini koji kreiraju kulturu, nismo ni prvi ni najslušaniji. Stoga nam je potrebna promjena pastoralnoga mentaliteta, što ne znači prelazak na relativistički pastoral. Nismo više u režimu kršćanstva, jer vjera posebno u Europi, na većemu dijelu Zapada - više ne predstavlja očitu pretpostavku zajedničkoga života, štoviše, niječe se, prezire, marginalizira, ismjehuje."7. Unatoč svim poteškoćama, primjereni pastoral, na temelju vjere, potiče ljubav prema istini i pomaže odgovorno prihvatiti bolne činjenice. Prihvaćajući društvena istraživanja, razmotrit ćemo, teološko-pastoralnom prosudbom, stanje crkvenog života i dati neke pastoralne smjernice. Jer, pastoral je pozvan hodočastiti s čovjekom na tešku i mirnu putu prema novom životu.

\section{TEOLOŠKO-PASTORALNA PROSUDBA PASTORALA I VJERE}

Svaka znanost, pa tako i pastoralna teologija, bavi se svojim posebnim predmetom (objekt). Nastojeći o interdisciplinarnosti, pastoralna teologija usmjerena je na proučavanje svega života i sveobuhvatnoga crkvenoga rada, odnosno radi se o materijalnomu predmetu, koji je zajednički i drugim teološkim znanostima. Osobita razlika između pastoralne teologije i drugih teoloških znanosti nalazi se u formalnomu predmetu, koji proučava sadanje povijesno stanje Crkve

$6 \quad$ Benedikt XVI., Porta fidei. Apostolsko pismo u obliku motuproprija kojim je proglasio Godinu vjere, KS, Zagreb, 2012., 2. Usp. Giuseppe Angelini, La fede, assensi a una dottrina? Origine e limiti di una formula, La Rivista del Clero italiano, (2013.), 6, 405-425.

$7 \quad$ Francesco, Discorso alla Curia romana per gli auguri di Natale (21. 12. 2019.). 
(hic et nunc). ${ }^{8}$ Sveti je papa Ivan Pavao II. (1978. - 2005.) svojedobno naglasio potrebu pastoralne ili praktične teologije „koja je znanstveni pogled na Crkvu u njezinoj svakodnevnoj izgradnji snagom Duha,

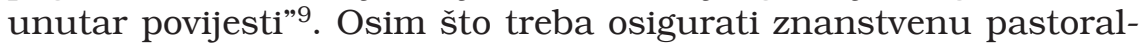
nu mjerodavnost, cjelovita pastoralna izgradnja moguća je samo uranjajući u otajstvo Presvetoga Trojstva. Da bi se spoznao životni smisao pastorala, nužna je, držeći se teološko-pastoralnih načela i mjerila, evanđeoska prosudba društveno-kulturnoga i crkvenoga ozračja. Pastoralna se izgradnja ne smije svesti samo na znanstveni istraživački rad, jer je odgovorni pastoralni rad potaknut vjerom i teološkim zahtjevima. Sukladno tomu, pastoralna teologija, vođena kriteriološko-kairološkim načinom, promatra sadanji i budući život Crkve, tj. praksu vjere (fides qua), odnos vjere i crkvenosti suvremenoga čovjeka. Duboko utkana u crkveni život, omeđena je novom evangelizacijom 'ad intra i ad extra' 10 .

Nova evangelizacija označuje navještaj evanđelja vjernicima, a osobito onima koji su ga upoznali, ali ga ne žive, posustali su u vjeri, a pripadnost Crkvi u njima je izblijedjela pa ne kušaju utjehu vjere, ponašajući se kao da nisu čuli za Isusa Krista. ${ }^{11}$ Radi se o ozbiljnomu pastoralnom poremećaju, koji treba veoma odgovorno raspraviti, jer se vjera osporava, kao pastoralna limfa. Kulturne promjene poslijemodernoga doba izazvale su prijepor, u kojemu se uočava poteškoća otvaranja nadnaravnim obzorjima i stvarnoj dosljednosti u odnosu s Bogom, koji nije uključen u nejasno vjerovanje u Boga (teizam) ili još nejasnije bezboštvo (ateizam). Radi se o pojavama koje se mogu definirati kao stanje "vjerskog ateizma" u kojemu se religioznost i njegove pojave ne poistovjećuju s kršćanskom, a ni s 'teističkom' vjerom. Vjerska odrednica promatra se s posve osobnog stajališta, u koje je svatko ugradio svoj osobni vjerski svijet, a

8 Paolo Asolan, Giona convertito. Paralipomeni di Teologia pastorale, Lateran University Press, Città del Vaticano, 2013., 13-31. Bruno Seveso, La pratica della fede. Teologia pastorale nel tempo della Chiesa, Glossa, Milano, 2010., 18-21. Josip Baloban, Pastoralna teologija u Hrvatskoj, u: Ivo Džinić - Ivica Raguž, Iščekivati i požurivati dolazak Dana Božjega. Zbornik radova u čast prof. dr. sc. Peri Aračiću prigodom 65. obljetnice života, Diacovensia, Đakovo, 2009., 15-32. Nikola Vranješ, Pastoral danas. Izabrane teme iz pastoralne teologije, GK, Zagreb, 2013., 17-140. Alojzije Čondić, Ustani, zove te. Bogoslovno-pastoralna razmišljanja, Crkva u svijetu (dalje: CuS), Split, 2013., 65-101.

9 Ivan Pavao II., Pobudnica Pastores dabo vobis, Nadbiskupski duhovni stol/GK, Zagreb, 1992., 57., usp. 58.

10 Usp. Maksym Adam Kopiec, Fede, testimonianza e nuova evangelizzazione, la teologia di fronte alle sfide odierne, Antonianum, 88 (2013.), 4., 602-608.

11 Usp. Pavao VI., Pobudnica Evangelii nuntiandi, KS, 2000., 26-39. Franjo, Pobudnica Evangelii gaudium, KS, Zagreb, 2013., 14. (dalje: EG). 
koji ne mora biti institucionalni ili kulturalni i ne može imati javno priznanje. ${ }^{12}$

Što se tiče vjerskoga života, raščlamba istraživanja istraživačkoga središta Pewa, u 34 europske zemlje, pokazala je da su Europljani manje pobožni od ljudi u drugim dijelovima svijeta. Religioznost Europljana razmatrana je pod četirima vidovima: sudjelovanje $u$ vjerskim obredima, učestalost molitve, vjerovanje u Boga i važnost vjere u osobnomu životu. Uočava se da su stanovnici Istočne i Srednje Europe religiozniji od stanovnika Zapadne Europe, u kojoj mnogi vjernici izlaze iz Crkve i postaju ravnodušni prema kršćanskomu iskustvu. Na primjer, u Armeniji, Grčkoj, Rumunjskoj te u Bosni i Hercegovini polovina odraslih izjašnjava se veoma religioznima, dok je u Danskoj, Švedskoj, Njemačkoj, Francuskoj ili Engleskoj samo jedan od deset stanovnika veoma religiozan. Razlike se uočavaju u Zapadnoj Europi; tako se npr. 37 \% Portugalaca izjasnilo kao veoma religiozno, a samo je 7 \% Čeha ili 6 \% Estonaca veoma religiozno. Podatci pokazuju da posve sigurno u Boga vjeruje $10 \%$ Nijemaca, $11 \%$ Francuza, 12 \% Engleza, 26 \% Talijana, 45 \% Poljaka, a 64 \% Rumunja, 66 \% žitelja Bosne i Hercegovine te 79 \% Armenaca. Mjesečno redovito moli 23 \% Španjolaca, 19 \% Iraca, 17 \% Rusa, 11 \% Šveđana, 6 \% Engleza, a u bogoslužju sudjeluje $61 \%$ Poljaka, 43 \% Talijana, 24 \% Nijemaca, $16 \%$ Norvežana, $10 \%$ Finaca. Istraživanje je pokazalo da $57 \%$ Hrvata postojano vjeruje u Božju opstojnost, $40 \%$ ih redovito moli na mjesečnoj razini, $40 \%$ ih ide na bogoslužje, a za njih $42 \%$ vjera ima važan smisao u životu. To su samo neki pokazatelji spomenutog istraživanja. ${ }^{13}$

Peto međunarodno istraživanje sustava vrjednota i primjene vrijednosnih smjerova pod nazivom European Values Study 2017./2018. godine (EVS), ${ }^{14}$ pokazalo je, u usporedbi s trećim (1999.) i četvrtim (2008.) istraživanjem, da u Hrvatskoj opada vjera u Boga, osobito kod muškaraca ( $15 \%$ ), a pad je najveći u skupinama od 31. godine života naviše. U uskrsnuće, raj i pakao vjeruje od $59,8 \%$ do $46,8 \%$ ispitanika. Radi se o nastavku udaljavanja u

12 Usp. P. Asolan, Non più mesta accanto al fuoco, Lateran University Press, Città del Vaticano, 2016., 8-10.

13 Usp. Jonathan Evans - Chris Baronavski, How do European countries differ in religious commitment? Use our interactive map to find out, $\mathrm{u}$ : https://www.pewresearch.org/fact-tank/2018/12/05/how-do-european-countries -differ-in-religious-commitment/ (19. 12. 2019.). Istraživanje je provedeno između 2015. i 2017. godine.

14 Usp. Josip Baloban - Gordan Črpić - Josip Ježovita, Vrednote u Hrvatskoj od 1999. do 2018. prema European Values Study, Katolički bogoslovni fakultet Sveučilišta u Zagrebu - Hrvatsko katoličko sveučilište - KS, Zagreb, 2019. 
odrednici vjerskih istina te povjerenja u Crkvu (39 \%). Pad se dogodio u obrednoj i na moralno-etičkoj dimenziji, jer je sve više onih koji podržavaju pobačaj, eutanaziju, rastavu, te se osjetno smanjuje tjedno pohađanje sv. mise i postotak onih koji bi zatražili krštenje svoga djeteta ili vjenčanje (godine 1999. sv. misu je tjedno pohađalo $32 \%$ ispitanika, dok ih je 2017 . godine $22,7 \%$, a onih koji nikada ne idu na misu $19,7 \%$ ). Polarizacija se dogodila 2018 . godine, jer 40,5 \% stanovništva ne pohađa vjerske obrede nikada ili rijetko kada, a 34,9 \% redovito (mjesečno ili češće). Premda postotak pripadnosti Katoličkoj Crkvi u Hrvatskoj ostaje znatan (80,3 \%), ipak se od 1999. godine do danas radi o distanciranoj crkvenosti u svim njezinim odrednicama, i to od vjerske pripadnosti do povjerenja u Crkvu. Ne ulazeći ovdje u dublje tumačenje crkvenosti, bitno je naglasiti da se radi o praktičnomu smanjenju crkvenosti u vidu teorije i prakse kršćanske vjere. S teološko-pastoralnog aspekta zabrinjavajuća je spoznaja razlike između odnosa pripadnosti nekoj vjeri i vjerskih istina, te je, u posljednje doba, opala vjera u Boga (od 7,6 \%). Premda u Boga vjeruje oko $85 \%$ ispitanika, ipak zabrinjava činjenica da samo $44 \%$ stanovnika vjeruje u osobnoga Boga, tj. u Boga Oca, koji se svijetu objavio u Isusu Kristu, $38 \%$ vjeruje ih u neku vrstu duha ili životne sile, a oko $25 \%$ ih vjeruje u reinkarnaciju; nereligioznih je $9,5 \%$, a ateista $5,4 \%$. Isto tako, povećao se broj ispitanika kojima vjera nije važna u životu (34,7 \%), a smanjio se postotak onih kojima je važna (63,9 \%), a i postotak onih koji drže da ih vjera tješi i ohrabruje (69,1\%). Onih koji svakodnevno mole ima oko $40 \%$, a $20 \%$ je onih koji nikada ne mole. ${ }^{15}$

Središnje pastoralno pitanje, kojim je zaokupljena pastoralna teologija i koje sa sobom povlači mnogo nejasnoća, jest kako novim naraštajima prenijeti vjeru u Trojedinoga Boga (traditio/reditio). Ne radi se o 'tehnici', nego o svjedočenju. Kako naviještati i govoriti o vjeri u Isusa Krista u pluralnomu društvu, koje sve više postaje bešćutno prema vjerskoj stvarnosti? U stvarnomu crkvenom biću, osobito u životu župne zajednice i u odnosu svećenika, ispod površine ključaju mnoge pastoralne dvojbe i nevolje, s kojima se Crkva treba neodgodivo i temeljito suočavati, a što se često izbje-

15 Usp. J. Baloban - J. Šimunović - J. Ježovita, Kretanje crkvenosti u hrvatskom društvu od 1999. do 2017. godine. Analiza i kritički osvrt, Bogoslovska smotra (dalje: BS), 89 (2019.), 2, 41 1-441. Krunoslav Nikodem - Siniša Zrinšćak, Između distancirane crkvenosti $i$ intenzivne osobne religioznosti: religijske promjene $u$ hrvatskom društvu od 1999. do 2018. godine, Društvena istraživanja, 28 (2019.), 3, 371-390. Istraživači raščlanjuju šest odrednica crkvenosti: odrednica vjerske pripadnosti, odrednica vjerske istine, obredna odrednica, moralno-etička odrednica, iskustvena odrednica i odrednica povjerenja u Crkvu. 
gava. Istraživanja pokazuju jaz i alarmantno stanje o crkvenosti, odnosno oslabljenosti aktualiziranja vjere u hrvatskomu narodu. Hrvati se diče svojim kršćanskim korijenima, baštinom i tradicijom, no nije dovoljno samo isticati prošlost bez izgrađivanja sadašnjosti i budućnosti. Osim naraštajne opustošenosti, postajemo li misionarska zemlja? Da bi se ostvarila pastoralna metanoja, stvorili pastoralni planovi i programi, nužna je dubinska pastoralna raščlamba na svim razinama, pa se crkveni rad mora posvetiti kontekstualnomu tumačenju, sukladno metodi evanđeoske prosudbe. Katkad se čini da prevladava bojazan upozoriti na neučinkovitost crkvenoga rada u postojećemu društveno-kulturnom okruženju. Poduzimanje prikladnih pastoralnih pothvata znak je pastoralne odgovornosti i osjetljivosti, odnosno prije svega zrele vjere.

Je li se kršćanstvo na našim područjima umorilo, je li Crkva postala pastoralno neodređena i gubi li svoju proročku ulogu? Je li dopustivo u doba "promjene vremena" šutjeti pred pastoralnim izazovima, smijemo li sve ostaviti kako je, bojimo li se promjena, jesmo li vjeru zaboravili prenositi i kako ostvariti novu evangelizaciju? Jesu li postojeći pastoralni modeli prikladni za XXI. stoljeće? Na uobičajenomu božićnom susretu s rimskim uredima, papa je Franjo, u surječju govora o promjenama u Crkvi, svoj govor završio riječima kardinala Carla Marije Martinija (1927. - 2012.): "'Crkva zaostaje dvije stotine godina. Kako to da se ne prodrma? Bojimo se? Strah umjesto hrabrosti? U svakomu slučaju, vjera je temelj Crkve. Vjera, pouzdanje, hrabrost (...) Samo ljubav pobjeđuje umor.." ${ }^{16}$ Bilo bi mudro ove misli ozbiljno prihvatiti uspoređujući ih s našim pastoralom. Zato svakako treba govoriti o uzrocima i razlozima smanjenja vjerskog života pitajući se „što nam je činiti?“ (Dj 2,38).

\section{UZROCI I RAZLOZI SMANJENJA VJERE I CRKVENOSTI}

Bilo bi nerazborito zapostaviti potrebu "povijesne svijesti", štoviše, nužno je "spoznati i razumjeti svijet u kojem živimo"17 i osvrnuti se na dosadanji pastoral, pa iz njega otkrivati i tražiti nove oblike i načine crkvenoga rada, pazeći da se ne bismo slijepo zapleli $\mathrm{u}$ postojećim pothvatima, u prilagođivanju određenomu trenutku, ili se pretvorili u puke futurologe. Vjera pomaže vidjeti dublje i dalje, a budućnost Crkve nazire se u onima koji crpe snagu iz dubokih

16 Francesco, Discorso alla Curia romana per gli auguri di Natale (21. 12. 2019.).

17 GS, 4. 
evanđeoskih korijena i onih koji proročki žive vjeru. Kada se korijeni počnu sušiti i vjera sagorijevati, u pitanje se dovodi opstojnost Crkve na nekom području i dolazi do "migracije vjere"18. Crkva bez vjere samo je okoštala društvena gradba i opustošena utvrda. Pastoralnu stvarnost moraju uznemiriti podatci koji upućuju na smanjenje vjere i crkvenosti, jer kako će ostati Crkva Isusa Krista, Crkva koja vjeruje u Boga koji je postao čovjekom i koja naviješta život poslije smrti? Vjera nije nepokretna stijena, koju ne treba njegovati, nego je kao "blago u glinenim posudama" (2Kor 4,7), koje se mogu razbiti i 'blago' brzo raspršiti, pa se zato treba otvoriti Božjemu milosrdnom utjecaju.

Spomenuta istraživanja upućuju na neodgodivo: žurno istraživati uzroke i razloge smanjenja crkvenosti i prijepora vjere hrvatskih katolika, gledajući ih s društveno-kulturnoga i teološko-pastoralnoga stajališta i poduzimati prikladne teološko-pastoralne pothvate u navještaju i prenošenju vjere. Nije dovoljno samo prigovarati i predstavljati se kao nepogrješivo mjerilo, nego treba odgovorno otkrivati uzroke nevolja, proučavati zahtjeve suvremenog doba, tražiti način kako govoriti o Bogu 'digitaliziranomu' čovjeku i vjerski prosuđivati "znakove vremena", da bi Crkva što učinkovitije vršila svoje poslanje u svijetu. Rješenje se ne nazire u bijegu od stvarnosti, nego u suočavanju s njom, jer je nedopustivo zatvarati oči i skrivati se iza teoloških odrednica i slogana prošlosti kada se "duboke i brze promjene postupno šire" na hrvatskomu području, jer se radi o "pravoj društvenoj i kulturalnoj preobrazbi, koja zahvaća također vjerski život"19.

\subsection{Društveno-kulturni uzroci smanjenja vjere i crkvenosti}

Nema jednostranog odgovora zašto vjera opada u Europi i Hrvatskoj, jer su mnogi i veoma zamršeni uzroci i razlozi smanjenja crkvenosti. Komunistička vlast ${ }^{20}$, koja je prezirala vjeru i progonila vjernike, stvarala je ‘humanizam' bez Boga, bezbožno društvo. Henri de Lubac (1896. - 1991.) to je utvrdio kao 'dramu ateističkog humanizma'21. Jednoumni sustav, niječući Boga i čovjeka, ostavivši nakon sebe nesagledivo pogubne posljedice, vjeru je promatrao

18 Enzo Bianchi, Kakva vjera?, KS, Zagreb, 2017., 33-35.

19 GS, 4.

20 Usp. Usp. Tomáš Halík, West und Ost. Europas doppelte Erfahrung, Stimmen der Zeit, (2020.), 1, 39-50.

21 Usp. Vincenzo Paglia, Prijatelju koji ne vjeruje, Sarajevo: Katolički bogoslovni fakultet / Zagreb: GK, 2015., 17-46. 
u marksističkomu sloganu kao "opijuma za narod”, tvrdeći da je vjera "privatna stvar" i dosljedno tomu nije imala pravo javnosti. Raspravljajući o crkvenomu radu, u Hrvatskoj je prevladavala 'piramidalna ekleziologija' i paternalistički, autoritarni ‘solo' pastoral. Nakon Drugoga svjetskog rata većina je stanovnika živjela na selu, gdje se pastoralno radilo prikladno selu. Pojavom urbanizacije i industrijsko-tehničkoga prevrata, osim što je poljuljan život utemeljen na vjeri, seosko se stanovništvo selilo u gradove, u kojima većinom nije bilo crkava ni pastoralnih mjesta. Stanovništvo se, osobito u gradskim sredinama, pod pritiskom i ponudama isključivoga sustava, sve više odvajalo od vjere i Crkve, a, s druge strane, uglavnom se primjenjivao seoski pastoralni oblik rada. ${ }^{22} \mathrm{U}$ selima se većinom držalo do vjere, običaja i Crkve, a u gradovima se razvijao liberalizam. U odgojno-izobrazbenom smislu mnogo je utjecalo ideologizirano školstvo, ostvarujući marksistički pogled na svijet, kao i ateizacija sveg društveno-kulturnog života. Prisilne režimske okolnosti postupno su slabile pripadnost crkvenoj zajednici, pa se župu smatralo pastoralnim "kućnim zatvorom", što je ometalo razvitak suradnje i suodgovornosti. Postupno je slabio cjeloviti kršćanski odgoj i prenošenje vjere, određeni dio nominalnih vjernika nije primao sakramente niti je odlazio na crkvene obrede. Crkva, koju su komunisti držali svojim najvećim neprijateljem, bila je prisiljena okrenuti se pastoralu ad intra, tj. zatvoriti se u 'geto sakristiju'. Pod dugogodišnjim pritiskom bio je moguć oblik crkvenoga rada usmjeren na svećenika kao jedinoga pastoralnoga nositelja, a vjernici su laici uglavnom bili pastoralno pasivni pa se tako iskrivljivala slika o Crkvi. Razvijala se samo crkvena odrednica vjere, i to na osobnoj, obiteljskoj i župnoj razini i prevladavao je oblik 'Crkva naroda', a odnosio se na sve krštene, tj. praktične i distancirane, bez obzira na produbljenu crkvenost. Osim nedjeljnih i blagdanskih okupljanja, na bogoslužju i na župnomu vjeronauku, druge su pastoralne zadaće bile zasjenjene. Unatoč otežanim okolnostima Crkva je razvijala mnoge pastoralno-katehetske pobude, a osobito je nastojala u odgoju u vjeri, u župnim i drugim kršćanskim zajednica-

22 Biskupi su u bivšoj državi, raščlanjujući društveno i crkveno stanje $u$ doba marksističkoga socijalizma, napisali: "U tomu smislu novi tip industrijskourbanog društva vrši snažan utjecaj i na preostalo selo te se tako kroz krizu naslijeđene kulture posvuda pomalja nova civilizacija. U njoj se vrlo često Crkva pojavljuje kao sociološki rubna stvarnost, religija se povlači u područje privatnoga života, a prijenos vjerskih vrijednosti ne osigurava više nijedna društvena struktura", u: Radosno naviještanje evanđelja i odgoj u vjeri. Temeljne smjernice o obnovi religioznog odgoja i kateheze (30. 9. 1983.), KS, Zagreb, ${ }^{2} 1992$., 7, usp. 8-10. 
ma. Ipak, župa se, kao jedino crkveno područje zajedničkoga života i kulture, postupno poistovjećivala s vjerskom uslugom i podjelom sakramenata, što je do danas ostavilo posljedice u svijesti vjernika i dinamičnosti vjere. ${ }^{23}$

Početkom devedesetih godina XX. stoljeća, promjenom iz marksističkoga sustava u demokratski, a u ratnomu vihoru, Crkvi su se otvorile brojne pastoralne mogućnosti. Time su nastale dodatne poteškoće, koje se do danas nisu posve nadišle, a tiču se pastoralne promjene, posvješćivanja važnosti prvoga navještaja vjere, poslanja vjernika laika, stvaranja participativnih pastoralnih ustanova, evangelizacije kulture i društva. Od Crkve se mnogo očekivalo, ali ona u početku nije bila pastoralno pripravna za rad u novim okolnostima. Ipak se Crkva nastojala uključiti u društvene promjene, pa je uveden vjeronauk u škole, potaknut je vojni pastoral, pokrenute su različite vjerske udruge i društva, u nekoj su mjeri otvorene medijske mogućnosti, potpisani su ugovori između Svete Stolice i Republike Hrvatske. Međutim, nije se sustavno radilo na promjeni pastoralne svijesti, koja bi odgovorila „znakovima vremena“. Nije bilo izgrađenih vjernika laika koji bi se dublje uključili u društvena, kulturna i politička zbivanja, potičući mogućnosti kojima bi se društvo oslobodilo komunističkih natruha i prokrčio put pravednijem društvu.

Hrvatsko je društvo nespremno i prebrzo prešlo u pluriformni sustav, što se osjetilo i u pastoralu, a još brže ga je zahvatila zahuktala sekularizacija, koja, pomoću različitih tehnologija, odnosno znanstveno-tehničkoga razvitka, s komercijalizacijom i hedonizmom, bitno utječe na poimanje kršćanske antropologije i na vjerski život. Opasnost je da čovjek postane puka tvar u proizvodnji i potrošnji. U poslijemoderno doba, koje je označeno različitim vjerovanjima, vrjednotama i pogledima na svijet, ionako izranjenu dušu vjernika bešćutno nagriza sekularizacija, koja, gradeći društvo bez postojanih uporišta, stvara gotovo nepremostivu duhovnu prazninu i umrtvljuje vjerski žar, što postupno vodi smanjenju vjere i crkvenosti.

Sekularizacija, koja se odvojila od predaje i Crkve, nezaustavljivo se širi na svim razinama. Tako se Crkva našla u posve novim okolnostima, pa, osim pojave društveno-kulturnoga pluralizma, na

23 András Máté-Tóth - Pavel Miklušćák, Nije kao med i mlijeko. Bog nakon komunizma. Na putu prema pastoralnoj teologiji Istočne (Srednje) Europe, KS, Zagreb, 2001. J. Baloban, Pastoralni izazovi Crkve u Hrvata, KS, Zagreb, 1992. Pero Aračić, "Jeremija, što vidiš?" (Jr 24,3). Crkva u hrvatskom tranzicijskom društvu, Diacovensia, Đakovo, 2001. P. Aračić - G. Črpić - K. Nikodem, Postkomunistički horizont, Diacovensia, Đakovo, 2003. 
površini se $\mathbf{s}$ vremenom očitovala različitost u Crkvi. Na te izazove crkveni rad ne uspijeva učinkovito odgovoriti dosadanjom pastoralnom paradigmom, a da bi bio dobro postavljen, treba proučavati novonastale okolnosti i evanđeoskom prosudbom stvarati prikladnu pastoralnu svijest. Bez dubinske teološko-pastoralne prosudbe, samoprosudbe i proročkoga načina, prevladavat će svjetovna kultura, koja se sve snažnije ograđuje od vjere i Crkve te bi mogla iz društva i kulture posve isključiti vjerske sadržaje.

Sekularizacija, koju mudro razotkriva Charles Taylor ${ }^{24}$ (1931.), podmukla je i prerasta u sekularizam i "novi ateizam" ${ }^{25}$, jednostavno raskršćanjuje društveni okoliš i pomoću tobožnje medijske neopredijeljenosti stvara bezlično kulturno okružje, razbija društveno i crkveno zajedništvo. Duhovno izgladnjeli, zaslijepljeni i prevareni čovjek svoju sreću i sigurnost često traži u virtualnomu svijetu, obilazeći trgovine ili pregledavajući po tzv. 'pametnim uređajima', čime se promiče sekularna religija. Zagušen ponudom informacija i ubrzanim načinom života, suvremenoga se čovjeka ometa u razmišljanju i življenju vjere. Perfidnost sekularizacije očituje se npr. u činjenici da tržišno gospodarstvo određuje načela, što se potvrđuje u radu nedjeljom, u promatranju ljudske osobe pretežno kao potrošača ili u 'promicanju rodne ideologije iskrivljujući naravno poimanje braka i obitelji' ${ }^{26}$. Stvara se novi oblik čovjeka i društva na gospodarstvenim temeljima. Stanje je ozbiljno za Crkvu, jer vjera gubi životno uporište, izvanjsko znakovlje, kao npr. promicanje svjetovnoga došašća po hrvatskim trgovima, dekonstruira kršćanske istine i guši unutarnju bît, a osim toga iščezava naraštaj koji je odgojen u kršćanskomu duhu, pa gotovo nestaje obiteljski oslonac kao prirodni izdanak vjernika, a postupno nastupa naraštaj iz sekularnog okružja. Stvara se društvo iz čijega obzorja iščezava Bog i čovjek, pa se promiče posvjetovnjačena vjera. Pastoralna je zadaća, kako zapaža Paolo Asolan, nadići podređenosti i stav obrambenoga

24 Usp. Michael Paul Gallangher, Mappe della fede. Dieci grandi esploratori cristiani, Vita e pensiero, Milano, 2011., 139-155.

25 Sjevernoamerički teolog John F. Haugt bavi se odnosom Boga i novoga ateizma, pa proučavajući neke zagovornike ateizma (Richard Dawkins, Sam Harris, Christopher Hitchens), nabraja neka njihova temeljna načela: osim prirode ništa drugo ne postoji, ne postoji Bog, ni duša, ni život poslije smrti. Priroda nije Božje djelo, nego se reproducira sama od sebe. Svemir nema nikakvu svrhu. Budući da Bog ne postoji, uzroci svega čisto su prirodni i objašnjivi samo znanošću. Vjera u Boga izvor je nebrojenih zala, moral ne zahtijeva vjeru u Boga a osobe se bolje ponašaju bez vjere nego s vjerom, u: Dio e il nuovo ateismo, Queriniana, Brescia, 2009., 19-20.

26 Usp. Kongregacija za katolički odgoj, "Muško i žensko stvori ih". Za put dijaloga o putanju roda u odgoju, KS, Zagreb, 2019. 
ponašanja, što je često označavalo kršćanski nadahnutu kulturu i što priječi suočavanje s pluralizmom i sekularizacijom u ključu prve/nove evangelizacije. Bitno je nadići bojazan i skrivanje vjernika od javnih i utjecajnih mjesta, koja stvarju pastoralna područja ad extra, jer, kako tvrdi Hans Urs von Balthasar (1905. - 1988.), "kršćanin se mora uključiti u svako područje svjetovne kulture"27.

Vjerski život i crkvenost potkopava također i kršćanska nedosljednost te različite vjerske patologije, koje ne žele crkvenu vjeru, nego neku svoju posebnu, uzimajući od kršćanstva što im sada koristi, a tomu pridonosi prosvjetiteljski pastoral, pastoralni individualizam, etički pluralizam i društveni materijalizam. Vjera i kršćanska predaja mnogima postaju svojevrsni 'baldahin' ispod kojega se prigodno skrivaju, a egzistencijalno promiču društvenu crkvenost i emocionalnu religioznost, više obred, a manje navještaj i svjedočenje, više promidžbu svjetovnosti, a manje zagovor evanđelja i Boga, što često vodi idolopoklonstvu i praznovjerju. S druge strane, prijeti zamka naglašavanja religijske fenomenologije, čime se gubi pastoralni noumen, tj. istinska bit pastoralnoga rada te olako može prevladati akcidentalni vid pred ontološkim. Time bi primjerice prigodom slavlja sakramenta potvrde ili ženidbe bila važnija vanjska svečanost od unutarnje poruke i biti sakramenta.

\subsection{Pastoralni razlozi smanjenja vjere i crkvenosti}

Sve utjecajniji sekularizam stvara nepovoljne uvjete za povećanje vjere, ali, osim društveno-kulturnih uzroka i razloga smanjenja vjere i crkvenosti, temeljna poteškoća nastaje u nedovoljnomu preustroju pastoralnoga rada. Promjena pastoralne svijesti prvotno bi trebala, ne samo održavati status quo nego ražarivati približavanje Bogu i Crkvi, iz uvjerenja, i naglašavati važnost promišljenoga temeljnog opredjeljenja za vjeru. Crkva je devedesetih godina prošloga stoljeća bila veoma ugledna u društvu, što se, kako pokazuju istraživanja, umanjilo. Stvaranjem hrvatske države mnogi su se, premda u doba komunizma nisu bili uvjereni vjernici, izjasnili kao katolici, no bez izvornoga života u katoličkomu duhu, o čemu je temeljito svojedobno pisao Stjepan Kušar (r. 1950.), govoreći o djelomičnomu prihvaćanju vjere i kršćanstvu po izboru. ${ }^{28}$ Poglavito se to vidjelo na primanju sakramenata, na prigodnim vjerskim obredima ili susretima, gdje su

27 Hans Urs von Balthasar, Vagliate ogni cosa, trattenete ciò che è buono, Lateran University Press, Roma, 2002., 43. (Intervista di Angelo Scola).

28 Usp. Stjepan Kušar, Djelomično prihvaćanje vjere - kršćanstvo po izboru, BS, 66 (1996.), 2/3, 319-345. 
takvi sudjelovali kao „nijemi promatrači“. Kod mnogih se više radilo o kulturološkomu ili civilizacijskomu kršćanstvu, negoli o životnomu uvjerenju i crkvenoj dosljednosti.

Teološko-pastoralni prijepor proizlazi iz činjenice da se mnogi koji su bili odgajani marksistički, nisu unutarnje duhovno obratili, nego se na staroga čovjeka nadogradila nova društvena stvarnost, tj. kako poučava sv. Pavao, nisu 'odložili ponašanje staroga čovjeka i obukli novoga čovjeka' (Ef 4,20-24; Kol 3,9-10). Roditelji su mahom upisivali djecu na vjeronauk, a da ni sami nisu bili upućeni u vjerske istine i crkveni život. Školski su vjeronauk pohađala djeca i nominalnih vjernika, a roditelji im nisu, zbog manjka osjećaja crkvenosti, znali prenositi iskustvo vjere i crkvenog života. Djeca i mladež izvršavali su svoju školsku obvezu, ali bez uključivanja u župnu zajednicu i školski vjeronauk. Takva vjera zapostavlja crkvenost i često ostaje na površini ili razumskoj spoznaji, što stvara samo privid kršćanske zbilje.

Odgovorni za pastoral, vjerujući da je postojeći, uglavnom birokratski pristup, učinkovit za održavanje vjerskoga duha, a možda i zbog nedostatka odvažnosti i manjka proročke uloge, crkveni rad nisu uspijevali osloboditi od bezličnosti. Crkveni se rad uglavnom svodi na katehizaciju djece, slavljenje mise i rad sa starima u starosnoj dobi. Bilo bi površno pastoral poistovjetiti s misom, jer je euharistija „vrhunac i izvor“ kojoj ih treba, sazrijevanjem u vjeri, dovesti. Osim toga, stvara se pastoralna napetost na relaciji župna zajednica i crkveni pokreti/nove zajednice ${ }^{29}$, koji se katkad nude kao zamjena župnoj zajednici pa su mnogi vjernici, živeći vjeru s naslijeđenim crkvenim uvjetima, zbunjeni pojavom ponekad zatvorenog i/ili otvorenoga oblika pokreta te crkvenih progresista i tradicionalista.

Stanje kršćanske poruke često umrtvljuje nepovezanost života i sakramentalnih slavlja, što produbljuje pastoralni nesklad, 'pastoralnu shizofreniju', život u društvu bez vjere, odnosno život 'kao da Boga nema'. Zbog prijepora vjere slavlje se sakramenata pretvara u puki građanski čin, koji može još neko vrijeme nekim ljudima biti zanimljiv, ali, u odnosu na narušenu kršćansku bit i pad crkvenosti, sve više zabrinjava koliko ce hrvatski puk, pred demografskim i migracijskim iskušenjima, uopće očuvati svoj kršćanski i kulturni identitet. ${ }^{30}$

29 Usp. Kongregacija za nauk vjere, Pismo Iuvenescit ecclesia, KS, Zagreb, 2017., $2,16-18$.

30 Stjepan Kušar je u spomenutomu članku, Djelomično prihvaćanje vjere kršćanstvo po izboru, str. 330., zapisao: „Svetinje, odnosno sakramenti nemaju više u prosječnoj svijesti našeg čovjeka koji se deklarira Hrvatom-katolikom 
U našim pastoralnim pothvatima posljednjih godina naglašava se školski vjeronauk i kratka sakramentalna priprema, da bi se, makar malo, ublažila pukotina između želja i stvarnosti. Mnogi se pripremaju, primaju sakramente i idu na župni vjeronauk, žele ih kao sastavni dio društvenoga obreda i općenito, a ne žele produbljenje vjere, pa najviše postoji ćudoredno ili deističko uvjerenje i ništa više. Dakle, nastaje poteškoća: kako razviti potrebu prema životu u vjeri? Ne može se prenijeti ono što se ne živi. Isto tako, ako se, pripremajući djecu i mladež za sakrament pričesti ili potvrde, ne radi s obiteljima, koje često nisu dovoljno katehizirane ni evangelizirane, postupno, kod djece i mladeži opada vjera. To je pokazatelj nepostojanja pravoga obraćenja i manjka pastorala sakramenta krštenja, kao temeljene pastoralne paradigme. Na vjeronaučnim susretima s roditeljima za sakramente nije dovoljno ograničiti se na 'tehničku' raspravu na štetu sadržaja vjere i duhovnosti. Mnogi roditelji, zbog utjecaja komunističkoga sustava i sekularizacije, nisu dovoljno poučeni u vjeri, pa je njihovo vjersko iskustvo i znanje slabo za djecu ostalo na neznatnoj vjerskoj razini, tj. lišeni su dublje spoznaje o savezu s Božjom milošću. ${ }^{31}$ Nužno im je potrebno vjersko iskustvo da bi vjeru prenijeli svojoj djeci. Oni su obično prenosili ono što se poistovjećivalo s plemenitim osjećajem, čime se teško dolazi do vjere, pa u izboru različitih religijskih ponuda kršćanstvo mnogima postaje samo jedna od kulturnih inačica. Osim toga, zapostavljen je sustavni župni rad sa srednjoškolcima a zanemaren je sveučilišni pastoral. S bogoslovno-pastoralnoga stajališta stvar nije primjereno postavljena, pa se otvaraju veliki izazovi za pastoralni rad i pripremu pastoralnih programa počevši od pastorala odraslih.

Nedovoljnosti crkvenosti pridonosi, kako naglašava papa Franjo, upadanje u zamku imanentizma, tj. u zabludu ugodne izdvojenosti, odnosno u zabludu povlačenja u pastoralnu usamljenost,

ono mjesto koje im pripada po logici evanđelja, već ono koje se nameće propagandom, krhotinama običaja i potrebom kompaktnosti nacionalnoga bića. U tom smislu Hrvat-katolik, onaj stariji kao i onaj novokomponiran, na brzinu pokršten, zapravo uopće nije religiozno socijaliziran u Crkvi. Njemu jest ona donekle potrebna, ali u mjeri u kojoj on otkriva da njezini u nacionalni kontekst uklopljeni simboli mogu biti rabljeni i manipulirani kao izraz kulturnog i povijesnog baštinjenog kršćanstva on šutke i neprimjetno ostaje na distanciji te Crkvu u najboljem slučaju uzima kao donedavno neophodnog a sada pomalo neshvaćenog čuvara nacionalnog identiteta. Za sada je još neizvjesno hoće li demokratska procedura i pluralizam svesti tu funkciju kršćanstva na minimum ili je čak ukinuti."

31 Usp. Socioreligijjsko istraživanje 'Vjera i moral u Hrvatskoj’, BS, 68 (1998.), br. 4. Europsko istraživanje vrednota - EVS - 1999. Podatci za Republiku Hrvatsku, BS, 70 (2000.), br. 2. 
koja se očituje u lažnoj nezavisnosti, u kojoj nema mjesta za zdravu duhovnost pa se pretvara u duhovnu potrošnju, po mjeri nezdravoga individualizma. Jer, „vjerovati ne možemo sami. Vjera nije samo neko osobno opredjeljenje u dubini vjernikova srca. ... Vjera se po svojoj naravi, otvara 'nama', događa se uvijek unutar zajednice Crkve"32. Međutim, društvenu i crkvenu zajednicu i zajedništvo, sprječavajući stvarne susrete, sve više priječi 'digitalna komunikacija' ${ }^{33}$, koja je umnogomu pastoralni kairos, ali, kako reče papa Franjo, također „ima svojih ograničenja i nedostataka“34. Neodgovorno korištenje tehnologije pridonosi uranjanju u virtualni svijet, što može produbiti distanciranje od vjerskih i društvenih vrijednosti, potencirati usamljenost i oslabiti navještaj vjere i razgovora. No, nepatvorena vjera $u$ Isusa Krista neodvojiva je od sebedarja i pripadnosti zajednici, služenja i pomirenja. Vjera ujedinjuje i preporađa život i narav kršćanske zajednice. Ali, vjeru mogu gušiti i oni koji se diče kršćanstvom, koji misle da su pravi katolici, a dušom i životom ne žive vjerski. ${ }^{35}$

Na spomenutomu tragu, prvotni pastoralni izazov nije bezboštvo, nego vjerska ravnodušnost, odnosno pitanje: kako na primjeren način odgovoriti na žeđ za Bogom mnogih ljudi, kako nadići kržljavu religioznost i stvoriti društveno mjesto u kojemu će se iskusiti snaga kršćanske vjere? Poteškoće vjere ne proizlaze samo iz Božje nevidljivosti i nenazočnosti već i iz činjenice da se ljudi moraju suočavati i s drugim poteškoćama, sa zlom i bolestima, s patnjom i tugom. Vjera nije izazvana toliko teorijskim ateizmom, koliko suprotstavljenim životnim predodžbama. Kako govoriti o Bogu i vjeri čovjeku kojemu je gotovo sve znanstveno-tehnički izvedivo i dostupno? ${ }^{36}$ Ako svećenik i vjernik laik nije „kvasac“ (Mt 13,33) i ako se vjera ne naviješta (Rim 10,14-17) i ne ponudi duhovnost i „Zdrav nauk“ (2Tim 4,1-5), izlaz će se tražiti u svjetovnim ili vjerskim nadomjestcima, a time se može lako upasti u zastranjenje i bezboštvo. Premda, s pastoralnoga vida, to može biti dobra prigoda, ipak nepovoljnu prigodu za navještaj stvara mnogo turističkih

32 Franjo, Enciklika Lumen fidei, KS, Zagreb, 2013., 39. (dalje: LF).

33 Usp. Manfred Spitzer, Usamljenost. Neprepoznata bolest, Ljevak, Zagreb, 2019., 112-136. Isti, Digitalna demencija, Ljevak, Zagreb, 2018., 104-123.

34 Franjo, Pobudnica Christus vivit mladima i cijelome Božjem narodu (25. 3. 2019.), KS, Zagreb, 2019., 88, usp. br. 86.-90.

35 Usp. Fabrice Hadjadj, Kako danas govoriti o Bogu?, Verbum, Split, 2018., 33-62. Isti, Kad se sve ima tako raspasti. Razmišljanje o svršetku kulture i moderniteta, KS, Zagreb, 2019., 158-159.

36 Thomas Frings, Gott funktioniert nicht. Deswegen glaube ich an ihn, Herder, Freiburg - Basel - Wien, 2019., 50-75. Roberto Mancini, Il senso della fede, Queriniana, Brescia, 2010., 30-36. 
ponuda, što se poglavito odražava na svijest djece i mladeži, koji su sve manje prožeti crkvenošću, vjerskim i nacionalnim identitetom.

U neoliberalnomu društvu, koje je zamračeno individualizmom i etičkom isključivošću, sve se više otvara praznina između etike i crkvenoga života, pa i praktični vjernici toleriraju duhovne i društvene anomalije, kao što su pobačaj, eutanazija, rastava, korupcija, iseljivanje, slobodne veze, genetički inženjering, robotizacija društva, ekologija, društvene nepravde. Neodrživa je etika odvojena od svetoga, jer postaje previše ograničena i prizemljena. Razumljivo je da su u relativističkomu društvu i prividnoj kulturi, kako zapaža papa Franjo u pobudnici Evangelii gaudium, sve privlačniji različiti oblici duhounoga blagostanja bez zajednice, teologija prosperiteta bez odgovornosti za bližnje ili subjektivna iskustva, koja se poistovjećuju $\mathrm{s}$ imanentističkim duhovnim zahtjevima. Pod utjecajem relativizma i laicizma urušava se vrijednosni sustav i kršćanska bit, pa prijeti napast duhovne svjetovnosti, koja se često skriva u krutosti.

Crkvenost i vjera opada ako se vjernike ne poučava kako otkriti Boga u svakomu čovjeku, Isusa u liku drugih, vjeru u riječi Božjoj, a za to vjernici, kao „stado malo“ (Lk 12,32), trebaju živjeti zajedništvo u župnoj zajednici, živeći evanđelje. Zamka je pomoću neodređene duhovnosti tražiti ljudsku slavu, a što se hrani gnosticizmom, tj. subjektivnom vjerom, koju zanima samo određeno iskustvo ili niz zasada i spoznaja, za koje se drži da mogu utješiti i prosvijetliti, a gdje pojedinac ostaje zatvoren u dosegu razuma i osjećaja. Jedan od razloga potiskivanja vjere otkriva se u prometejskomu neoplagijanizmu onih koji se uzdaju samo u svoje snage i smatraju se većima od drugih, jer su vjerni katoličkomu načinu ponašanja iz prošlih vremena. Tu se krije narcisoidni i podčinjujući elitizam, koji umjesto da olakša pristup milosti, snagu troši na nadzor i provjeru, a, kao najgore, ne pokazuje se zanimanje za Isusa Krista i to je zabluda tzv. antropocentričnoga imanentizma. Ispriječila se zamka pastoralnoga neognosticizma, prema kojemu čovjek, bitno samodovoljan, spašava sama sebe neovisno o Bogu, tj. ne shvaćajući smisao svetopisamske vjere, ne misli na vječni život ili smatra da će se spasiti uzdajući se u svoje snage i ljudsku pomoć. Zbog potiskivanja vjere u tim se pojavama krije zamka pretvaranja Crkve u svjetovne ustanove, $\mathrm{u}$ menadžerski rad, parlamentarno promatranje, što potiče zaokupljanje podatcima, fenomenologijom, planiranjima, koji Crkvu vide kao političku stranku ili tvrtku, a ne kao Božji narod, koji se sabire snagom Duha Svetoga. ${ }^{37}$

37 Usp. EG, 76-108. Kongregacija za nauk vjere, Pismo Placuit Deo, KS, Zagreb, 2018. Franjo, Pobudnica Gaudete et exsultate, KS, Zagreb, 2018., 35-62. 


\section{MiLOSNI DAR I DUBINSKI KORIJENI VJERE}

Vjera je sredstvo odnosa $s$ Bogom. Zato vjerovati znači biti na Božjim valovima, na njegovim valnim duljinama, osluhnuti njegov naum, osjećati njegovu pomoć, imati povjerenje u život, jer kršćanin vjeruje da ga Bog štiti. U suprotnomu, stvara se puka religija, pa čovjek i Crkva postaju predmet materijalističkih, odnosno sociološko-psiholoških raščlamba ili medijsko-političkih previranja. Poslanica Hebrejima poručuje da "je vjera već neko imanje onoga čemu se nadamo, uvjerenost u zbiljnosti kojih ne vidimo" (Heb $11,1)$. Osim prihvaćanja sadržaja kršćanske vjere, koji se podudara s objavom, vjerovati znači osobno, kao ljudski čin, stajati postojano u Bogu, pripadati Kristu i susresti Isusa Krista.

Bez vjere nema pastorala, jer bi se pastoral pretvorio u tehnomenadžerski posao, odnosno pretvorio bi se u tehničko-praktičnu granu, koja se bavi dnevnim religijskim zbivanjima, ne misleći o onostranosti. Ako se s vjerom ne 'istinuje u ljubavi i ne poradi da sve uzraste u Krista' (Ef 4,15) opasnost je da se služenje, poziv i poslanje Crkve (sakramenti, kateheza i karitas) pretvore u pragmatizam, svjetovnu religioznost i humanizam. Crkveni rad otkriva Božju istinu i djelo u svijetu, a ostvaruje poslanje spasenja, jer je dužnost vjernika učiniti sve da neprestano u svijetu "riječ Gospodnja trči i proslavlja se" $(2 \mathrm{Sol} 3,1)$. Ako vjera i spasenje nisu međusobno upućeni i zavisni, gubi se, kako kaže papa emeritus Benedikt XVI., motivacija za vjeru. ${ }^{38}$ Djelotvornom se vjerom slavi Boga (Mt 11,25) i naviješta kraljevstvo Božje $(M k$ 1,15). Ako kršćani ne razmišljaju o životu nakon smrti, ako ne vjeruju u susret i život s uskrslim Kristom i u njegov ponovni dolazak, ako je ostvarivo spasenje bez Krista i Crkve, ${ }^{39}$ vjera postaje isprazna, pa se gubi evangelizacijski i misionarski smisao i žar vjernika u svijetu.

Vjera uključuje razum, uvažava ljudsku slobodu, pa se povezuje s povijesnim i kulturnim kontekstom u kojemu čovjek živi, razmišlja i odlučuje. Ta se spoznaja sigurno zrcali u Lukinu evanđelju, u govoru o susretu Isusa s deset gubavaca (Lk 17,11-19). Gubavci su bili jedinstveni moleći Isusa da im pomogne, ali nakon ozdravljenja samo se Samarijanac vratio, slaveći Boga i zahvaljujući Isusu. Gubavomu Samarijancu Isus reče: "Ustani! Idi! Tvoja te vjera spasila!" Odnos devetorice gubavaca prema Isusu bio je samo pojavni, društveni,

38 Usp. Benedetto XVI., Cos'è la fede?, u https://www.avvenire.it/agora/pagine/ facciamoci-plasmare-da-cristo- (15. 2. 2020.).

39 Usp. Kongregacija za katolički odgoj, Doktrinarna nota o nekim aspektima evangelizacije, KS, Zagreb, 2008., 7. 
dalek, površan. Tražili su svoju korist i samo su tjelesno ozdravili, a vjera Samarijanca bila je spasenjska, dubinska i suradnička. On se vratio, poklonio, zahvalio i Isusa susreo izbliza. Ozdravio je tjelesno i spasio se duhovno. Samarijanac je svojim činom očitovao sakrament ispovijedi i euharistije. Usporedno s tim, konačni smisao pastorala je pobuditi vjeru, čija je svrha "spasenje duša" (1Pt 1,9). Spasenjska vjera (usp. Rim 10,9), koja ne čisti samo tijelo, nego spašava cijelu osobu, proizlazi iz susreta Isusa i čovjeka. Dok liječnička znanost nije uznapredovala kao danas, mnogi su kršćani vjerovali da mogu ozdraviti uzdajući se u Božje milosrđe. Međutim, kakva je vjera suvremenoga čovjeka, je li uštogljena, samo građanska religija, civilizacijski čin, sinergija koristoljublja, idolopoklonstva i praznovjerja ili je božanska, postojana, vertikalna, plodna?

Kao što se u Isusu ujedinjuje božansko i ljudsko, tako i vjeru treba shvaćati kao božansko, kao dar Božjega milosrđa, i antropološko, kao otvorenost ljudskoga duha i srca daru vjere i svega onoga što vjera čini u ljudskomu biću, tj. kako ona utječe na njegovu osobnost, razmišljanje i ponašanje. Za učinkovitu vjeru treba susret, jedinstvo božanskoga i ljudskoga, jer kako govoriti o kršćanskoj vjeri bez suodnosa sadržaja i čina vjere, koja teži ukorijenjenosti u ljudskom životu, a usmjerena je Isusu Kristu. Takva je vjera životno usmjerena. No pitanje je zašto vene vjera u europskim i hrvatskim katolicima, zašto neki vjeruju, a neki ne vjeruju, zašto ona u nekima brzo usahne, a u drugima donosi obilat plod?

Odgovor na to nalazimo u Isusovoj prispodobi o sijaču (Mk 4,120). Bog, kao velikodušni sijač, sije Riječ, darove svoga milosrđa, vjeru, a plod sjetve zavisi o "vrsnoći tla". Ne radi se samo o pojedincu nego i o vrsnoći društveno-kulturne i pastoralne podloge. Ako 'tlo’ nije obrađeno za usjev, teško se može očekivati plod. Tako i vjera, ako se ne oplemeni ozračje za njezin rast, kako očekivati njezine plodove? Mnogi Crkvu ne doživljuju kao mjesto koje uprisutnjuje Isusa kao smisao života, pa u kršćanstvu uglavnom vide prigodu za obiteljska slavlja i emotivno uporište za kulturni identitet. Korov može zagušiti sjeme, maslina može prolistati i ostati neplodna. Svijet se ubrzano mijenja, a vjera, u odnosu na prošla vremena, kada ju je poticalo obiteljsko okruženje, sve više postaje stvar osobnog izbora, a širi se duhovno neosjetljivi mentalitet. Na tomu se tragu naslućuje opadanje vjere i vjerskoga života, jer, ometani sekularizacijom i osobnom duhovnom lijenošću, mnogi kršćani ne stvaraju ni unutarnje ni vanjsko ozračje za rast vjere. Ipak, ne smije se previdjeti da Božje milosrđe, o kojemu govori papa Franjo, pobuđuje vjeru i omogućuje joj da prosvijetli razum, jer vjera je temelj ono- 
mu što nadilazi svaku mogućnost ljudskoga razuma i pomaže mu otvoriti se Božjoj objavi. Bog je otajstvo u koje čovjek proniče vjerom, a razum joj pomaže u njezinoj vjerodostojnosti. Kršćanska je vjera 'razumna' vjera, pa ljudsko umovanje ne može zamijeniti vjeru, jer vjera je dar milosti, a Bog svojom milošću prosvjetljuje razum. ${ }^{40}$ Nužno je temeljno znanje o vjeri, odnosno kako će netko vjerovati ako ništa ne razumije i ako se slobodnom voljom ne otvara vjeri? ${ }^{41}$ Vjera se ne može odreći razuma, jer kako će vjernici biti "spremni na odgovor svakomu koji od vas zatraži obrazloženje nade koja je u vama” $(1 \mathrm{Pt} 3,15)$.

Papa Franjo zagovara božansko i ljudsko milosrđe. Milost vjere je dar (talent) (Mt 25,14-30), kojim treba razborito upravljati da bi ga se umnožilo. Suodnos pastorala i vjere podrazumijeva milosrđe i pravednost. ${ }^{42}$ Vjera nije svima dana na isti način, nije u svima ista, pa postoje razlike $u$ iskustvu vjere. Nužno je prihvaćati tu stvarnost, tj. uzeti u obzir vjeru koju ljudi imaju, jer je bez toga teško uspostaviti ljudski i pastoralni suodnos. U suprotnomu, ako se polazi od obične sintagme vjere, teško je razumjeti i prihvatiti traženje i hod u vjeri, jer vjera je stupnjevit pojam. Činjenica je da nije svima jasno Presveto Trojstvo, zašto vjerovati, da svi vjernici nemaju istu jakost vjere i da u mnogima vjera postupno trne. Neki su udaljeni, stidljivi su, ali to još uvijek ne znači da su bezbožni, i zato je izazov pastoralu kako pobuditi zaspalu vjeru. Odnosi u obitelji nisu uvijek isti, nije isto iskustvo vjere, a djeca koja imaju poteškoće s roditeljima, imat će drukčije iskustvo vjere. Život u vjeri i ozračje prenošenja vjere danas je mnogo zamršenije nego prije. Da se Crkva ne bi pretvorila

40 Usp. T. Halík, Il cammino che porta nel profondo, u: Anselm Grün - Tomáš Halík, Fare a meno di Dio? Se fede e incredulità si cercano, Queriniana, Brescia, 2017., 154-164. Jean-Luc Marion, Credere per vedere, Lindau, Torino, 2012., 39-79.

41 Usp. Josef Pieper, O vjeri. Filozofska rasprava, KS, Zagreb, 2012., 13-32. Paul Tilich (1886.-1965.) tvrdi da je vjera u svetopisamskom smislu čin sve osobnosti. Volja, znanje i osjećaji sudjeluju u njoj. Ona je čin samodarivanja, poslušnosti, pristanka. Emocionalno predanje bez pristanka bila bi prisila, dok umni pristanak bez osjećajnoga sudjelovanja razara vjersku bit u neosobni čin. Poslušnost volje bez pristajanja i osjećaja vodi u depersonalizirano ropstvo. Vjera ujedinjuje i nadilazi posebne uloge ljudskoga uma. Svetopisamska vjera vjera je zajednice, naroda ili Crkve. Onaj tko se približi zajednici, mora prihvatiti njezine sustave vjere i sustav vjerovanja, u: Biblijska religija i potraga za krajnjom zbiljnošću, $\mathrm{KBF}$ Sveučilišta u Zagrebu/KS, Zagreb, 2016., 55-56.

42 Franjo, Bula najave izvanrednoga jubileja milosrđa Misericordiae vultus, KS, Zagreb, 2015., 12: „Crkva ima zadatak naviještati Božje milosrđe ... U ovo vrijeme, kada se Crkva posvećuje zadaći nove evangelizacije, temu milosrđa treba uvijek iznova predlagati s novim zanosom i novim pastoralnim djelovanjem. Za Crkvu i za vjerodostojnost njezina navještenja od presudne je važnosti da ona sama živi i svjedoči milosrđe.”. 
u neprobojni sektaški zid, odnosno da bi očuvala katolištvo, zapaža Tomáš Halík (r. 1948.), pozvana je nastojati oko ljudi, koji, kao Zakej (Lk 19,1-10), zauzimaju mjesto na rubu vidljive Crkve. S teološko-pastoralnoga stajališta manjkavost se osjeti u 'ekleziocentrizmu', tj. usmjerenosti Crkve na samu sebe, pa se treba usmjerivati i na udaljene i nevjernike.

Nakana je mnogih sekularista vjeru svesti samo na osobni čin, niječući činjenicu da je vjera u 'isti mah osobni i zajednički čin'. Ona se, svojom naravi, kao i svjetlo, očituje u stvarnomu životu. Papa Benedikt XVI. naučava da "ispovijedati ustima, pak, znači da vjera podrazumijeva javno svjedočenje i djelovanje. Kršćanin nikada ne smije smatrati vjeru privatnim činom, jer pojava privatizacije religije i svođenje vjere na emocionalno područje potiskuje Boga iz života. Vjerovati znači odlučiti biti s Gospodinom, da bi se živjelo s njim. A to čovjekovo „biti s njim“ uvodi ga u shvaćanje razloga zbog kojih se vjeruje. Vjera, upravo zato što je slobodni čin, zahtijeva također društvenu odgovornost za ono što se vjeruje. Crkva na dan Pedesetnicu krajnje jasno pokazuje tu javnu dimenziju vjerovanja i neustrašivoga svjedočenja svoje vjere svakom čovjeku.”. ${ }^{43}$

Da bi se vjerski mogla promatrati životna, društvena i pastoralna stvarnost i da ne bi usahnula, vjeru treba hraniti Božjom riječju, molitvom, sudjelovanjem u bogoslužju, sakramentima, produbljivanjem duhovnog iskustva, djelima milosrđa. Ako se vjernik tim ne otvara Božjemu daru vjere, ako ne surađuje i ne produbljuje dar vjere, ostaje na površini i ne može uroniti u njezine dubine, odnosno, zbog manjka vjere, ne može naučiti čitati između redaka. Kršćanska vjera nije puko ljudsko uvjerenje o Božjoj opstojnosti, nego ulivena božanska krjepost, kojom sam Bog proniče u ljudski život. Bez vjere se ne može shvatiti smisao patnje i sumrak života, odnosno samo se s vjerom može uroniti u noć i zimu Božje šutnje i živjeti s tajnom, jer u suprotnomu čovjek upada u vjerske zablude. Zato je često dramatična borba između vjere i nevjere. S pastoralnoga vida, bitno je razabrati da vjera nije jednoznačna, jer postoje različite inačice vjere, tj. među vjernicima (nominalni i praktični) postoje velike razlike. Pastoral nužno osluškuje vjeru. Vjera i pastoral su uključivi, suodnosni su. Pastoral treba osluškivati čovjeka, pa se u tomu dijaloškomu odnosu prilagođuje.

U konačnici, vjera, drži Tomáš Halík, poima život kao dijalog, a bez vjere život postaje monolog. Osoba vjere sposobna je šutjeti i slušati, pitati i odgovorno živjeti. Razlika između postojane vjere 
i egzistencijalnog nedostatka vjere očituje se $u$ tomu što je život $u$ vjeri otvoren dubinama, dolazi iz dubine, a u suprotnomu radi se o životu koji se 'gradi na pijesku' (Mt 7,26), na površini. Tko tvrdi da ima vjeru, a istodobno živi u plićaku, možda ima vjersko uvjerenje, ali nije osoba vjere kako je Isus naviješta. Postoji religioznost koja se trudi steći vjeru, 'posjedovati' religioznu sigurnost ili Boga, odnosno "imati” vjeru. Ali, kršćansko shvaćanje vjere teži „biti“" u vjeri, tj. oblik žive vjere jest neprestano traženje puta koji vodi u dubine otajstva, jer biti u vjeri znači napredovati i ostati u vjeri, 'graditi život na stijeni' (Mt 7,24). Na tomu se tragu može govoriti o dvama različitim oblicima vjere: 'izvanjskoj religioznosti', koja je izvana uvjetovana, i 'unutarnjoj religioznosti'. U izvanjskoj religioznosti vjera služi kao 'sredstvo' za nešto drugo, tj. netko želi biti dio neke skupine ili steći čvrsta uvjerenja u životu i povezuje se s određenim autoritetima, a u vidu 'unutarnje vjere' osobe vjeruju da su veoma povezane s evanđeoskom porukom Isusa Krista. ${ }^{44}$

\section{TEOLOŠKO-PASTORALNE SMJERNICE ZA PRODUBLJENJE CRKVENOSTI I VJERE}

Kriza života vjere na svim područjima, osim što se posljedično događa zbog dalekosežnog utjecaja komunističkog sustava i sve utjecajnijega relativizma i sekularizacije, očituje se i u činjenici što mnogi smatraju da se još uvijek, kao nekada, reprodukcija krščanstva odvija uglavnom u obitelji i u podjeli sakramenata. Takva zamisao stvara pastoralno umrtvljenje i Crkvu vodi u zabludu, misleći da će se kršćanstvo samo od sebe razvijati, rođenjem i sakramentalizacijom. Nekad su, poglavito u homogeno doba, societas christiana, društvo nadahnuto kršćanskim vrijednosnim sustavom, osobito roditelji i obitelj, bili naravni okvir i poticatelj prenošenja vjere i života u sakramentima. Tada se nije toliko kao danas razmišljalo o novoj evangelizaciji, prvomu navještaju, katehizaciji ili misionarskomu obliku pastorala, jer je obitelj prenosila vjeru. No društvenokulturno okružje posve se promijenilo, pa brak i obitelj, zbog društvene i pastoralne neodređenosti, više toliko ne utječu. Stoga je pastoralno prvenstvo u obitelji i među obiteljima "razlijegati prvi navještaj" 45 , promicati novu evangelizaciju obitelji, počevši od sakramenta krštenja kao pastoralne paradigme, jer "slabljenje vjere i vjer-

44 Usp. T. Halík, Il cammino che porta nel profondo, 164-174. Isti, Strpljenje s Bogom. Pripovijest o Zakeju danas, Svjetlo riječi, Sarajevo, 2015.

45 Franjo, Enciklika Amoris laetitia, KS, Zagreb, 2016., 43. (dalje: AL). 
ske prakse u nekim društvima odražava se na obitelj, ostavljajući ih još osamljenijima usred njihovih teškoća" ${ }^{46}$.

Spomenuti oblik prenošenja vjere prekinut je u sekularnomu svijetu, na koji kršćanske vrjednote sve manje utječu, a zaraženi svijet za vjeru postaje bitno otežan. Ipak, u tomu spletu treba tražiti mjesto navještaja vjere, stvarati okruženje u kojemu se može svjedočiti i prenositi vjera, promicati sustavan i cjelovit, a ne samo masovan, spontan i usputan pastoralni oblik. Neupitna je sakramentalna struktura vjere i važnost sakramenata za vjeru, o čemu govori enciklika Lumen fidei, ali za živu vjeru nije više dovoljno prenositi vjerske sadržaje i obilježavati pastoralne obljetnice, jer se vjera rađa u susretu i ostvaruje se u odnosima zajedništva s Bogom i drugima, u Crkvi i s Crkvom. Prenosi se s osobe na osobu, kao što se vatrom pali druga svijeća. ${ }^{47}$

Budući da opada vjerski život, nije utješno samo izvanjski podijeliti sakramente, držeći da će plodovi niknuti sami od sebe. Bitno je pročistiti i osvježiti pastoralno sjećanje i rad te stvarati uvjete za oživljenje vjere, jer je zrela vjera djelotvorna i ustrajna u tami života. Ako se riječ Božja i sakramenti primaju u dubokoj pobožnosti i vjerskoj osviještenosti, na temelju iskustva Božje blizine u Isusu Kristu, i ako ljudi mogu 'upoznati Božju nježnost prema njima', tada će kršćanstvo, unatoč materijalističkomu gušenju, imati mjesto za rast i učinke. Mnogi primaju sakramente bez duhovne spoznaje, katehetske i pastoralne priprave, odnosno bez dubokog uvjerenja i ukorijenjenosti u Isusu Kristu, štoviše, pristupaju pretežito zbog izvanjske religioznosti, društvenog folklora i tradicionalnih običaja. Manjka umreženost kršćanskih odrednica: kateheze, sakramenata i karitasa. Time se koristi vjera i crkveno poslanje, što je svojevrsni znak vjernicima, osobito crkvenomu vodstvu, da se preispitaju stvaraju li primjereno ozračje za rast vjere u obiteljskim, župnim i biskupijskim zajednicama te kulturnom okolišu. Očito je žurno, osobito na župnim razinama, ali nadilazeći župne granice, umrežavati pastoral, stvarati pastoralna područja, oblikovati animatorske uloge, molitvene i svetopisamske zajednice i u njima doživljavati iskustvo vjere. Zato je nužna preobrazba pastorala, nova evangelizacija u misionarskomu ključu, što podrazumijeva pastoralni rad s onima koji ne Žive u svojoj vjeri. ${ }^{48}$

\footnotetext{
$46 \quad$ AL, 43.

47 Usp. LF, 37-49.

48 Usp. EG, 25-36. Severino Dianich, Comunicare la fede al non credente: il primo fra i molti significati di „evangelizzare“, Credere Oggi, 32 (2012.), 5, 22-31.
} 
Danas prevladava svojevrsno pastoralno uzmicanje i skrivanje iza dogmatskih definicija, što crkveni rad ostavlja na izvanjskosti, kao da se sve rješava samo od sebe, pa župni pastoral zaostaje. Bez uključivanja duhovne osjetljivosti i molitve, gdje se zajednički traži iskustvo Boga, gdje se zajednički raspravlja, gdje se vjerska iskustva i spoznaje pokušavaju prereći na jednostavan i razumljiv način, vjera će se teško produbiti. Male župne skupine u kojima se njeguje osjećaj crkvenosti, bitne su, jer se u njima ne ustručava iznijeti svoje iskustvo ili manjak iskustva vjere da bi ona rasla. Treba znati da ima i onih čiji 'umor od Crkve' izrodi 'umor vjere', pa izlaz traže $\mathrm{u}$ 'aktivnostima nekih malih zajednica ili nekih crkvenih pokreta, pa pitanja razuma nastoje nadići buđenjem osjećaja i sugestivnom snagom masovnih skupova'. Ako izblijede obrisi Božjega lica, kršćanska poruka i pastoral usuđuju se svesti na društveno-religiozne usluge ili na religijsku emocionalnost, stav i populizam bez evanđelja i spasenjskoga djela Isusa Krsta.

Jedna od bitnih zamki u pastoralu je što neki dušobrižnici pretpostavljaju da je vjera kod mnogih vjernika zrela i živahna, pa zaboravljaju svoj rad usmjeriti na rast vjere i crkvenosti. Ako se pretpostavi da je vjera sazrela kod djece i mladeži za pripremu na sakrament pričesti i potvrde, njihovih roditelja ili kod pripravnika na sakrament ženidbe, može se pomisliti da je sve drugo važnije od pobude vjere, pa se pastoral usmjeruje na tehničke umjesto na duhovne sadržaje. Svojedobno je, nadahnut mislima Hansa Ursa von Balthasara, papa Benedikt XVI. naglasio da se vjera ne smije pretpostaviti, nego predlagati, poticati, naviještati. Vjera u svijetu nije sačuvana sama po sebi, ne prenosi se automatski u čovjekovo srce, nego se uvijek mora objavljivati i započeti od srca koje ljubi Isusa. Stoga je za pastoral presudno stvarati plemenito ozračje za vjeru i naviještati Isusa Krista. Vjerovati znači odlučiti se za Isusa, biti ustrajan i strpljiv, jer strpljenje i poniznost vjeri daju spasenjsku snagu. Poniznost i strpljenje su otvor kroz koji se Božja milost ulijeva u našu vjeru, odnosno ognjište, na kojemu Bog može zapaliti vatru svoga duha, a "ljudsku vjeru" pretvoriti u "božansku vjeru". ${ }^{49}$

U jednom članku ne može se sve reći o vjeri i pastoralu, ali se može upozoriti da vjera nije zamjena za razum, niti postoji razlog za međusobno nadmetanje. Među njima postoji 'duboka i neprekidna uzajamnost', čiju osjetljivu ravnotežu treba neprestano istraživati i nadzirati da se ne bi nepopravljivo kompromitirali. Naime, "razum,

49 Usp. Benedetto XVI, Discorso al Convegno ecclesiale della diocesi di Roma (13. 6. 2011 .). T. Halik, Strpljenje s Bogom, 221-223. 
lišen objave, zalazi na stranputicu koja dovodi do opasnosti da se ne vidi krajnji cilj. Vjera bez razuma iznosi osjećaje i iskustvo te tako upada $\mathrm{u}$ opasnost da više ne bude sveopća ponuda. Pogrješno je misliti da je vjera pred slabim razumom moćnija; naprotiv, ona sama dospijeva $u$ opasnost da postane bajkom ili praznovjerjem. Na isti način razum pred kojim se ne nalazi čvrsta vjera, nije više izazvan promotriti novost i radikalnost samoga 'biti"”50. Kao što bi razumnost bez duhovnih poticaja iz vjere postala drska i opasna, tako bi se i vjera bez prosudbe pretvorila u slabokrvni svjetonazor. ${ }^{51}$ Isto tako, treba podsjetiti da su razlozi vjere i razlozi srca, a ne samo spekulativne inteligencije, jer je dug put od razuma do srca.

Pastoralne smjernice uključuju temu 'komunikacije' i 'komunikativne teologije'52, jer se dijalog i navještaj vjere nikada ne suprotstavljaju. Komunikacija se ne ograničava samo na tehnička sredstva, nego teži antropološkoj i društvenoj vrijednosti, što upućuje na bit poteškoće, a odnosi se na kulturu, jer se bez usmjerenosti na istinu kultura pretvara $u$ relativizam. Očito je da razlozi vjere vode u kulturu ${ }^{53}$, tj. sve ono što oblikuje način razmišljanja, ponašanja i duhovno ustrojstvo. Mnogima je veoma teško spojiti govor o milosrdnomu Bogu i svakodnevna iskustva. Stoga je bitno preispitati što naviještaju i kako svećenici i vjernici laici u svojim propovijedima i nagovorima, katehezama i duhovnim sadržajima povezuju evanđeosku poruku sa životom. Budući da vjeri prijeti opasnost da potamni u svjetovnomu ozračju, treba učiniti sve da se kršćanska vjera vrati u crkveno i kulturno okružje, predstavljajući se na očit i bitan, smislen i razumljiv način. U suprotnomu, ako se propovijedanjem evanđelja ne živi zajedničko iskustvo vjere i navještaja, opasnost je samorazumljivoga Boga pretvoriti u nepoznatoga Boga. Bez autentičnosti evangelizacija društva i kulture postaje neplodna, jer sekularizirano društvo rastače kulturu, u kojoj su normativni čimbenici uporište društva, i na takvu se polju sjeme Božje riječi suši. Bitno je učinkovito utjecati na vraćanju kulturno uvjerljivih izgleda kršćanskim zajednicama, počevši od župnih zajednica. Poteškoća je ako ljudi tražeći smisao i preispitivanje odnosa sa svi-

$50 \quad$ FR, 48.

51 Usp. Jorge Mario Bergoglio (papa Franjo) - Abraham Skorka - Marcelo Figueroa, Razum i vjera, dostojanstvo, molitva, solidarnost, Verbum, Split, 2014., 13-31.

52 Usp. Jadranka Garmaz-Matthias Scharer, „Učenje” vjere. Kako osmisliti i voditi proces učenja vjere? Komunikativnoteološka koncepcija, GK, Zagreb, 2014., 121-149.

53 Joseph Ratzinger, Vjera, Istina, Tolerancija, KS, Zagreb, 2004., 60.: "Vjera jest kultura. Ona ne postoji u golom stanju, kao puka religija. Jednostavno time što ona čovjeku veli tko je on i kako treba započeti bivati čovjekom, vjera stvara kulturu, ona jest kultura." 
jetom ne nađu zajednice i crkveni život koji nude u takvu traženju životna mjesta, jer pastoralni rad tada gubi na važnosti. Nužno je da župne zajednice na svim svojim područjima postanu mjesta traženja i otkrivanja smisla, životnoga prosvjetljenja, mjesta koja će tražiti i poticati nadu, vjeru i ljubav prema Bogu i jednih prema drugima. ${ }^{54}$

Pastoralni rad treba osmišljavati u njegovim oblicima i na svim temeljnim područjima, uravnotežiti ga u misionarskom smislu, $\mathrm{tj}$. prijeći s autoreferencijalnog načina na misionarski oblik, ali ne kao na izniman pothvat, nego kao na temeljnu odrednicu. To je nužno, jer se crkvene ustanove ne mogu više postavljati prema društvu kao da su svi stanovnici dosljedni vjernici, što se očitovalo na narodnom izglasavanju o braku i obitelji te Istambulskoj konvenciji. Redoviti pastoral, da bi učinkovito prenosio vjeru, ne će se moći podudarati s uobičajenim radom niti će se moći odrediti na temelju deduktivnih načela, nego ga treba oblikovati u stvarnomu okruženju (hic et nunc). Nužan je duboko i prikladno prilagođen, kapilaran i dubinski pastoral, usmjeren prema područjima (obitelji, mladeži, slobodnom vremenu, kulturi...), koji će se moći, osobno i zajednički, otvoriti ad extra, svjedočiti istinu vjere, kao neiscrpno svjetlo razuma, pokazati da Bog nije apstraktno, nego temeljno pitanje, o kojemu zavisi cijela ljudska opstojnost, naviještati vjeru u misaonim i životnim okvirima suvremenog čovjeka. U pastoralu treba neprestano razmišljati i moliti, preispitivati vjeru i crkveni život i u novim okolnostima tražiti prikladnije načine za navještaj vjere i produbljenje crkvenosti, jer ne postoje „nikakvi gotovi recepti”. 55

\section{ZAKLJUČAK}

Suočavanje s pluralizmom i sekularizacijom, u svim njezinim zamršenim i dvosmislenim zahtjevima, kršćane bitno preispituje, odnosno nameće se smjer odgovornog svjedočenja vjere. Vjera nije subjektivno shvaćanje, nego treba biti izgovorena, naviještena, imati crkveni oblik, jer, ako je usahnula, upitna je i crkvenost. Crkva, kao 'čuvarica izvorne duhovne snage ljudskoga života', ljudima nadom vjere omogućuje smisao, što ih čini slobodnima i bogatima, daje im snagu za služenje. Raščlanjujući društvene pojave i crkveni rad, lako

54 Usp. EG, 68-73. Benedikt XVI., Poruka Božjemu narodu prigodom otvaranja Trinaeste redoune biskupske sinode od 7. do 28. listopada 2012. godine. S. Lanza, La parrocchia..., 105-11. Isti, Convertire Giona. Pastorale come progetto, OCD, Roma, 2005., 217-220. P. Asolan, Non più mesta accanto al fuoco, 10, 250-252.

55 Peter Neuner - Paul M. Zulehner, Dođi kraljevstvo tvoje. Praktična ekleziologija, Ex libris, Rijeka, 2015., 263. 
se utvrdi da se radi o prijeporu vjere i crkvenosti, što stvara ozbiljne pastoralne i društvene poteškoće. Unatoč svim istraživanjima i statističkim podatcima, ne smije se upasti u razočaranje, beznađe i bezvoljnost. Štoviše, treba ustrajati u poslanju navještaja evanđelja nadom, utemeljenoj na spoznaji da je pastoralni rad prije svega djelo milosti, da njime ravna Duh Sveti, koji „puše gdje hoće” (Iv 3,8), pobuđuje znakove svoje nazočnosti i pomaže vjernicima bolje shvatiti poruku koju naviještaju. Jer „milosrđe je sam temelj na kojemu počiva život Crkve" 56 pa se treba otvoriti daru vjere.

Da bi se razvio osobni i crkveni čin i žar vjere, oživjela crkvenost i obnovio pastoral, Crkva je pozvana neumorno predstavljati sebi i drugima važnost sakramentalnoga susreta s Isusom, u kojemu se čovječanstvu otkriva otajstvo ljubavi Boga Oca. U pastoralu ne treba izmišljati nestvarne pothvate, kao da je pastoral na religijskomu tržištu, nego treba ustrajno, s čvrstom vjerom, duhovno i razborito, proučavati način kako je Isus Krist činio i te čine primijeniti na suvremeni život. Nije jednostavno naći učinkovit odgovor na smanjenje vjere i crkvenosti, ali žurno treba, sustavnim kršćanskim odgojem, u svojim zajednicama i kulturi, pružati oaze života, odnosno umnažati „zdence“ (Iv 4,5-42), na kojima će se utažiti duhovna žeđ i pratiti ljude da ne klonu duhom. Crkva je pozvana prije svega na osobno duhovno obraćenje, tj. evangelizacija je moguća samo ako vjernici osluškuju riječ Božju, koja potiče da se rodi vjera, jer otvaranje navještaju vjere vodi obraćenju, a Duh Božji svojom snagom obnavlja Crkvu.

Sekularizacija od Crkve traži preispitivanje i razmišljanje o svojoj nazočnosti u društvu, kulturi i svomu pastoralnom radu. Nova je evangelizacija nezamisliva bez navještaja evanđelja i prenošenja vjere obiteljima, u čemu je bitno shvatiti ulogu odgoja. "Vjera je primjeren odgovor čovjeka Bogu koji govori" 57 , a evangelizacija traži odvažan navještaj vjere u Isusa Krista i novi savez vjere i razuma, što jača poslanje kršćanskih zajednica u odgoju i kulturi, društvenoj povezanosti i medijima, dijalogu sa znanošću i umjetnošću, politikom i gospodarstvom.

\footnotetext{
56 Franjo, Misericordiae vultus, 12.

57 Benedikt XVI, Pobudnica Verbum Domini, KS, Zagreb, 2011., 25.
} 


\section{FAITH AND PASTORAL CARE}

\section{Summary}

The basic pastoral challenges imposed by secularization include religious indifference, i.e. the reduction of religious life and incoherence of church feelings. If faith is taken to be the way by which salvation can be achieved, then faith and its application in life refer to the essence of the Church and her mission. Accordingly, the writer, in a theological-pastoral way of evangelical judgment, based on scientific research, connects the relationship between faith and pastoral care in church life, in Europe and Croatia, and then talks about the causes and reasons for the decline of faith and churchliness. Analysing the cultural context of Croatian society and pastoral work, he speaks of faith as a gift of grace, for which a gentle atmosphere should be continually created so that faith may multiply as fruitfully as possible among the faithful. The writer of the article then proposes pastoral guidelines on the necessity of pastoral metanoia and the way to deepen faith and churchliness.

Keywords: churchliness, faith, pastoral care, culture, reason, evangelization, proclamation. 